\title{
1 \\ The Australian Prison Population and Daily Life in Australian Prisons
}

\section{Introduction}

Prisons do not exist in a vacuum. Nor does prison law. The legal and other obligations that apply to prisons are greatly influenced by the society in which those prisons operate and the people that are held in them. This chapter provides the statistical and sociological context for the remainder of the book by providing an overview of key aspects of Australian prisons and imprisoned people.

The first part of the chapter provides a picture of the prison population in Australia. This includes the statistical profile of the Australian prison population, and an outline of the characteristics of this population and some of the ways it differs from the general population. ${ }^{1}$ The unifying feature of this distinctiveness is vulnerability: the prison population contains an over-representation of vulnerable segments of the general population, including Indigenous Australians and people with mental health problems and cognitive disability.

\footnotetext{
1 The statistics in this chapter are based on Australian Bureau of Statistics data released in December 2019 drawn from a prison census conducted on 30 June 2019.
} 
The second part of the chapter examines the sociological literature about daily life in Australian prisons. This is important background as to why this particular population requires the human rights protections that form the subject of the remainder of this book.

Men comprise the majority of the Australian prison population and for this reason much of the sociological literature focuses on men's experience of imprisonment. However, because women are one of the fastest growing sub-groups of the Australian prison population and because they have particular vulnerabilities, the first part of this chapter will also outline the statistical profile and vulnerabilities of the female prison population. ${ }^{2}$ Selected references will be made to the treatment of women in Australian prisons throughout the remainder of the book. However, it should be noted that women's imprisonment is not the sole focus of this book and imprisoned women's vulnerabilities are sufficiently complex that they alone could be the subject of an entire book.

\section{The Australian Prison Population}

The prison population of Australia cannot be completely captured by statistics and simplified categories, but there are three key features. The first is how many people are incarcerated, including the trend of these numbers increasing over time (with overcrowding as the corollary). The second is the disproportionate imprisonment of members of certain groups of the general population, particularly Indigenous Australians. ${ }^{3}$ The third is the characteristics that make people in prison a vulnerable group within Australian society.

Vulnerability is the norm rather than the exception in the Australian prison population. This bears out Garland's observations about the function of the prison within what he terms the 'culture of control'. ${ }^{4} \mathrm{He}$ argues

2 The female prison population rose consistently from 2011-18 before dropping by 4 per cent in 2019. The male prison population has been increasing since 2012, but not at as high a rate as the female prison population: Australian Bureau of Statistics, Prisoners in Australia 2019 (5 December 2019) ('ABS 2019').

3 The first two themes are taken from Garland, who writes, 'imprisonment ceases to be a fate of a few criminal individuals and becomes a shaping institution for whole sectors of the population': David Garland, 'Introduction: The Meaning of Mass Imprisonment' in David Garland (ed), Mass Imprisonment: Social Causes and Consequences (SAGE, 2001) 2.

4 This is a framework for understanding developments in crime control in the United States of America (USA) and United Kingdom between 1975 and 2000 that can be generally characterised as involving increasing punitiveness. 
that prisons are used as a means of 'segregating the problem populations created by today's economic and social arrangements'. ${ }^{5}$ Garland's approach echoes Australian authors, such as Cunneen et al, who argue that prison "has been reconstituted as a "therapeutic institution" providing a solution not only to serious criminal behaviour but also to behaviour seen as too difficult to manage in the community'. ${ }^{6}$

\section{Imprisonment Statistics and Rates}

As at 30 June 2019, there were 43,028 people in Australian prisons (a combination of those who have been sentenced, and those on remand), resulting in an overall imprisonment rate of 219 per 100,000 (409 per 100,000 males and 35 per 100,000 females). ${ }^{7}$ Because criminal law, sentencing and prisons are a state/territory responsibility, there are variations in both the imprisonment rate and the growth of imprisonment rates across jurisdictions. The imprisonment rates for each state and territory are provided in Table 1.1 in ascending order (by the overall imprisonment rate), with the male and female imprisonment rates provided in separate columns. These rates are from the annual prison census conducted on 30 June 2019.

Table 1.1: Imprisonment Rates in Australian Jurisdictions as at $\mathbf{3 0}$ June 2019

\begin{tabular}{|l|c|c|c|}
\hline Jurisdiction & $\begin{array}{c}\text { Total imprisonment } \\
\text { rate per 100,000 } \\
\text { of population }\end{array}$ & $\begin{array}{c}\text { Male imprisonment } \\
\text { rate per 100,000 } \\
\text { of population }\end{array}$ & $\begin{array}{c}\text { Female imprisonment } \\
\text { rate per 100,000 } \\
\text { of population }\end{array}$ \\
\hline $\begin{array}{l}\text { Australian } \\
\text { Capital Territory }\end{array}$ & 143.2 & 274.9 & 19.5 \\
\hline Victoria & 157.1 & 297.8 & 22.0 \\
\hline Tasmania & 164.7 & 308.4 & 25.6 \\
\hline South Australia & 207.3 & 394.6 & 37.9 \\
\hline $\begin{array}{l}\text { New South } \\
\text { Wales }\end{array}$ & 213.6 & 404.0 & 29.7 \\
\hline
\end{tabular}

5 Garland, above n 3, 199.

6 Chris Cunneen et al, Penal Culture and Hyperincarceration. The Revival of the Prison (Ashgate, 2013) 285-6. A similar argument is made in relation to prisons in the USA by Loïc Waquant, 'Deadly Symbiosis: When Ghetto and Prison Meet and Mesh' in David Garland (ed), Mass Imprisonment: Social Causes and Consequences (SAGE, 2001) and, more broadly, David Scott, 'Unequalled in Pain' in David Scott (ed), Why Prison? (Cambridge University Press, 2013) 315 and the authors cited therein.

7 ABS 2019, above n 2.

8 Ibid, Table 17.

9 Ibid.

10 Ibid. 


\begin{tabular}{|l|c|c|c|}
\hline Jurisdiction & $\begin{array}{c}\text { Total imprisonment } \\
\text { rate per 100,000 } \\
\text { of population }\end{array}$ & $\begin{array}{c}\text { Male imprisonment } \\
\text { rate per 100,000 } \\
\text { of population }^{\mathbf{9}}\end{array}$ & $\begin{array}{c}\text { Female imprisonment } \\
\text { rate per 100,000 } \\
\text { of population }\end{array}$ \\
\hline Queensland & 224.8 & 415.0 & 42.8 \\
\hline $\begin{array}{l}\text { Western } \\
\text { Australia }\end{array}$ & 344.7 & 623.0 & 70.2 \\
\hline $\begin{array}{l}\text { Northern } \\
\text { Territory }\end{array}$ & 942.0 & $1,708.3$ & 128.5 \\
\hline Australia & 218.6 & 409.0 & 34.9 \\
\hline
\end{tabular}

The Northern Territory's rate of imprisonment is particularly startling. ${ }^{11}$ As Scott observed, '[i]n March 2012 the Northern Territory had a prisoner rate of 821 per 100,000, which, if it was a nation in its own right, would be the number one penal incarcerator in the world'. ${ }^{12}$ This rate has risen since 2012 and is much higher for males. As Table 1.1 shows, the rate of male imprisonment in the Northern Territory is $1,708.3$ per 100,000. To put this into perspective, the World Prison Brieflists the highest imprisonment rate in the world as the United States of America's (USA's) rate of 655 per $100,000 \cdot{ }^{13}$

The rate of imprisonment in Australia grew by 10 per cent between 2002 (when it was 152 per 100,000) and 2012 (when it reached 167 per 100,000) before rising higher still to the 2019 rate shown above of 218.6. ${ }^{14}$ This has occurred despite overall crime rates declining. ${ }^{15}$

Although the rate of growth varies between states and territories, growth is a common feature across all jurisdictions and is a trend that applies regardless of which political party is in power (explanations for this growth and how it might be addressed are considered in Chapter 4). In the period between 2012 and 2013, the Australian Bureau of Statistics reported an upward trend in all jurisdictions except Western Australia and Tasmania. ${ }^{16}$

11 The Northern Territory's imprisonment rate has been higher than the national average for many years. For example, in 2008, the Northern Territory's male imprisonment rate was 1,111.9 per 100,000 while the national average was 320.3 per 100,000: ibid, Table 15 .

12 Scott, above n 6, 5.

13 International Centre for Prison Studies, World Prison Brief <http://www.prisonstudies.org/worldprison-brief>. Similar to Australia, the USA's rate varies when broken down on a state-by-state basis.

14 Australian Institute of Criminology, Australian Crime: Facts and Figures: 2013 (2014) Chapter 6 ('AIC 2013').

15 Ibid, Foreword. There are some exceptions to the general trend of declining crime rates. For a detailed discussion see Rick Sarre, 'The Importance of Political Will in the Imprisonment Debate' (2009) 21(1) Current Issues in Criminal Justice 154, 157-8 and the statistics in ibid.

16 Australian Bureau of Statistics, Prisoners in Australia 2013 (2014). 
Taking a longer-term perspective, Weatherburn compared the increases in imprisonment rates across jurisdictions between 2002-16 and found an increase of 81 per cent in South Australia, 78 per cent in the Northern Territory and 74 per cent in Western Australia. ${ }^{17}$ The Victorian Sentencing Advisory Council documents that the Victorian imprisonment rate increased by 40 per cent between 2002 and $2012 .{ }^{18}$

The consequence of this rapid growth in the prison population is overcrowding, which is an increasing problem in Australian prisons. ${ }^{19}$ The Victorian Auditor-General has highlighted that the 'nationallyaccepted limit for the safe and efficient operation of the prison system' is a 95 per cent utilisation rate. ${ }^{20}$ Yet the Report on Government Services highlights that secure facilities nationally were operating at 121.2 per cent of capacity in 2016-17 (the most recent year for which a reliable national rate is available), ${ }^{21}$ with West Australian secure prisons operating at 132.8 per cent capacity in $2018-19 .^{22}$ The Victorian Ombudsman referred to overcrowding in Victorian prisons as a 'crisis' in 2014, writing that '[a]s a result of overcrowding, people detained in custody in Victoria face a greater risk of harm than any time in the past decade'. ${ }^{23}$

Overcrowding is a theme that recurs throughout this book because it is a major factor precluding human rights compliance in Australian prisons. It will be seen that overcrowding is itself often a breach of human rights (such as when it leads to two or three people being held in a cell designed for one), but it also indirectly causes or worsens distinct breaches of human rights (such as when the stresses of crowded prisons leads to greater violence).

17 Don Weatherburn, 'Australian Imprisonment 2002-2016: Crime, Policing and Penal Policy' (2018) 51(4) Australian \& New Zealand Journal of Criminology 537, 538.

18 Sentencing Advisory Council, Victoria's Prison Population 2002-2012 (2013).

19 Termed 'hyperincarceration' by Cunneen et al, above $\mathrm{n} 6$.

20 It was noted in the report that this rate 'allows prison management the flexibility to adequately manage the rehabilitation, human rights and welfare of prisoners. Operating above 95 per cent utilisation compromises the ability of prison management to safely and humanely manage prisoners': Victorian Auditor-General, Prison Capacity Planning (2012) 9.

21 Steering Committee for the Review of Government Service Provision, Report on Government Services 2018, Volume C: Justice (Commonwealth of Australia, 2018) 8.14, Table 8A.13. The figure is 115.6 per cent for 2017-18, but Victoria, New South Wales and South Australia did not provide data and, given that Victoria and New South Wales operate two of the larger prison systems in Australia, this skews the data: Steering Committee for the Review of Government Service Provision, Report on Government Services 2019, Part C: Justice (Commonwealth of Australia, 2019) 8.17.

22 Steering Committee for the Review of Government Service Provision, Report on Government Services 2020, Volume C: Justice (Commonwealth of Australia, 2020) Table 8A.13.

23 Victorian Ombudsman, Investigation into Deaths and Harms in Custody (2014) 10. 


\section{Over-Representation of Certain Population Groups}

This section will cover four of the population groups that are overrepresented in the Australian prison population: (1) Indigenous Australians, (2) people with mental illness or cognitive disability, (3) people from disadvantaged locations and (4) older people.

The general national picture is captured well by Cunneen et al when noting, the rapid increases in imprisonment rates across Australian jurisdictions (and arguably elsewhere) from the mid-1980s onward, while clearly variable and far from uniform across the Australian states and territories, can be seen as predominantly composed of Indigenous men, women and juveniles'. ${ }^{24}$ This book does not deal with juveniles, but will deal with the other main sub-groups, as well as some additional aforementioned sub-groups. This is because juvenile detention is a specialised area and under international human rights law, the starting position (that juvenile detention should only be used 'as a measure of last resort and for the shortest appropriate period of time $^{25}$ ) is different to the starting position that applies in relation to adult imprisonment (this will be detailed in Chapter 2).

\section{Indigenous Australians}

The over-representation of Indigenous Australians in prison is striking. Indigenous people (men and women) make up 28 per cent $(11,866)$ of the national adult prison population despite only comprising 2 per cent of the general adult population. ${ }^{26}$ This means that the overall national imprisonment rate of 219 per 100,000 cited above, when broken down by Indigenous status, is 162 for non-Indigenous Australians and 2,349 for Indigenous Australians. ${ }^{27}$ It also means that if the imprisonment rates in Table 1.1 were separated by Indigenous and non-Indigenous by jurisdiction, the imprisonment rate for non-Indigenous people would be lower and the difference even more striking. A useful way of characterising the figures is that Indigenous Australians are approximately 13 times more likely to be imprisoned than non-Indigenous Australians. ${ }^{28}$

\footnotetext{
24 Cunneen et al, above n 6, 182. Cunneen defined women and the first three categories as 'Suitable Enemies: Penal Subjects': at Chapter 5.

25 Convention on the Rights of the Child, opened for signature 20 November 1989, 1577 UNTS 3 (entered into force 2 September 1990), art 37(b). Australia ratified this Convention on 17 December 1990.

26 ABS 2019, above n 2, Table 2.

27 ABS 2019, above n 2, Table 17.

28 Human Rights Watch, 'I Needed Help, Instead I Was Punished': Abuse and Neglect of Prisoners with Disabilities in Australia (2018) 20.
} 
The Indigenous imprisonment rate varies around the country. For instance, the imprisonment rate for Indigenous people in Western Australia is 70 per cent higher than the national imprisonment rate. ${ }^{29}$ The imprisonment rate for Indigenous people in each of the states and territories is shown (in ascending order) in Table 1.2 alongside the Indigenous proportion of the prison population in each jurisdiction.

Table 1.2: Indigenous Imprisonment Rates in Australian Jurisdictions as at 30 June 2019

\begin{tabular}{|l|c|c|}
\hline Jurisdiction & $\begin{array}{c}\text { Indigenous imprisonment rate } \\
\text { per } \mathbf{1 0 0}, \mathbf{0 0 0} \text { of population }^{\mathbf{3 0}}\end{array}$ & $\begin{array}{c}\text { Indigenous proportion of } \\
\text { prison population (\%) }^{\mathbf{3 1}}\end{array}$ \\
\hline Tasmania & 777.3 & 20.2 \\
\hline New South Wales & $1,879.9$ & 23.1 \\
\hline $\begin{array}{l}\text { Australian Capital } \\
\text { Territory }\end{array}$ & $1,944.2$ & 21.9 \\
\hline Queensland & $2,098.7$ & 32.8 \\
\hline Victoria & $2,267.7$ & 10.4 \\
\hline South Australia & $2,551.1$ & 23.8 \\
\hline Northern Territory & $2,837.4$ & 83.4 \\
\hline Western Australia & $4,105.7$ & 38.6 \\
\hline Australia & $2,349.2$ & 27.6 \\
\hline
\end{tabular}

The over-imprisonment of Indigenous people is even more acute when particular communities are examined. For example, in the town of Papunya, Northern Territory, 72 out of the total population of 308 adults (23 per cent) were imprisoned during 2007-08. ${ }^{32}$ Such a high imprisonment rate has implications for the entire community.

The Indigenous imprisonment rate is growing rapidly. Between 2004 and 2018 , the Indigenous prison population rose by 88 per cent, whereas the remainder of the prison population rose by 28 per cent. ${ }^{33}$

29 The Honourable Wayne Martin (Chief Justice of Western Australia), 'Indigenous Incarceration Rates. Strategies for Much Needed Reform' (Speech, 2015) 4. The figures quoted in this speech were from the Australian Bureau of Statistics in 2014 when the rate was 3,663 per 100,000 in Western Australia and 2,174 per 100,000 nationally. For a discussion of possible causes see Hilde Tubex et al, 'Western Australian Penal Culture and Indigenous Over-Representation: Evaluating 25 Years of Law, Policy and Practice' (2018) 43(1) The University of Western Australia Law Review 264.

30 ABS 2019, above n 2, Table 17.

31 Ibid, Table 14.

32 Melanie Schwartz, 'Building Communities, Not Prisons: Justice Reinvestment and Indigenous Overimprisonment' (2010) 14(1) Australian Indigenous Law Review 2, 4-5.

33 Human Rights Watch, above n 28, 21. 
Indigenous women represent the fastest growing sub-group in the Australian prison population overall. Human Rights Watch report that they are ' 21 times more likely to be incarcerated than their non-indigenous peers' ${ }^{34}$ This rate also varies across jurisdictions. For example, in Western Australia, Indigenous women comprise more than 50 per cent of the female prison population. ${ }^{35}$

Indigenous incarceration was the subject of a recent in-depth inquiry by the Australian Law Reform Commission, which produced a detailed report in December 2017. The report found that over-representation of Indigenous people in prisons is the culmination of over-representation at every stage of the criminal justice system (being arrested, charged, prosecuted and sentenced). ${ }^{36}$ The report also found that Indigenous people were disproportionately more likely than non-Indigenous people to receive a custodial sentence, rather than a community-based sentence. ${ }^{37}$ The report contained a number of recommendations to address this situation and the main recommendations concerning justice reinvestment will be considered in detail in Chapter $4 .{ }^{38}$

\section{People with Mental IIIness or Cognitive Disability}

There are high rates of mental illness and cognitive disability across the prison population. The precise proportion of imprisoned people with mental illness varies according to the definition of mental illness used. The Australian Institute of Health and Welfare reports that 35 per cent of male prison entrants and 37 per cent of male prison dischargees fall into the category of 'reported being told by a health professional that they had a mental health condition (including alcohol and other drug use disorders)'. The figures are 65 per cent and 38 per cent respectively for females. ${ }^{39}$

\footnotetext{
34 Ibid 23.

35 Martin, above n 29, 4. The figures quoted in this speech were from the Australian Bureau of Statistics in 2014.

36 The executive summary reports, 'Over-representation increases with the stages of the criminal justice system. In 2016, Aboriginal and Torres Strait Islander people were seven times more likely than nonIndigenous people to be charged with a criminal offence and appear before the courts; 11 times more likely to be held in prison on remand awaiting trial or sentence, and 12.5 times more likely to receive a sentence of imprisonment': Australian Law Reform Commission, Pathways to Justice - An Inquiry into the Incarceration Rate of Aboriginal and Torres Strait Islander Peoples, Report No 133 (2017) 26.

37 The executive summary reports, 'Up to $45 \%$ of Aboriginal and Torres Strait Islander offenders sentenced in 2015-2016 received a sentence of imprisonment of less than six months. Few received a community-based sentence': ibid.

38 These were recommendations 4-1 and 4-2 contained in Chapter 4 of the report: ibid 137-8.

39 Australian Institute of Health and Welfare, The Health of Australian Prisoners 2018 (2019) 28. This is based on individuals' responses when 'asked whether they had ever been told that they have a mental health disorder by a doctor, psychiatrist, psychologist or nurse': ibid 137-8.
} 
Other studies range from indicating that 30 per cent of the prison population have been diagnosed with a mental illness ${ }^{40}$ to 80 per cent of the prison population having a psychiatric illness over a period of 12 months. ${ }^{41}$ One study of females in South Australian prisons, which had an 81 per cent participation rate, found that all respondents had a psychiatric disorder. ${ }^{42}$

Moreover, it has been reported that 20 per cent of the prison population have an intellectual disability, ${ }^{43}$ and as many as 80 per cent of imprisoned people have a history of brain trauma (depending on the definition used). ${ }^{44}$ A Victorian study reported that 40 per cent of the prison population had an acquired brain injury, compared to 2 per cent of the general population. ${ }^{45}$

These categories overlap. Many people present with comorbidity, such as 'mental or cognitive impairment with a substance abuse disorder', with Cunneen et al arguing that this group, often referred to as those having 'complex needs', is 'a large and neglected group' within the prison population. ${ }^{46}$

Despite a lack of comprehensive data on this subject, it is generally agreed that Indigenous people in prisons also display complex mental health needs. ${ }^{47}$ Human Rights Watch reported in 2018 that '[a]bout 73 percent of Aboriginal and Torres Strait Islander men and 86 percent of Aboriginal

40 Victoria Herrington and Katrina Clifford, 'Policing Mental Illness: Examining the Police Role in Addressing Mental Ill Health' in Isabelle Bartkowiak-Théron and Nicole Asquith (eds), Policing Vulnerabilities (Federation Press, 2012) 117.

41 Tony Butler et al, 'Mental Disorders in Australian Prisoners: A Comparison with a Community Sample' (2006) 40 Australian and New Zealand Journal of Psychiatry 272. A NSW study from 2003 found that ' $[\mathrm{t}]$ he 12-month occurrence of any psychiatric disorder (psychosis, anxiety disorder, affective disorder, substance use disorder, personality disorder or neurasthenia) was 74 per cent amongst prisoners': cited by Cunneen et al, above n 6, 97.

42 Claire O'Connor 'Victims or Offenders? Mental Health Issues in Women's Prisons' (2007) 81 Precedent 26, 27.

43 Terese Henning, 'Vulnerable Suspects and Arrest and Investigative Processes' in Isabelle Bartkowiak-Théron and Nicole Asquith (eds), Policing Vulnerabilities (Federation Press, 2012) 218.

44 James Huntley, 'Acquired Brain Injury and Vulnerability to the Criminal Justice System' in Isabelle Bartkowiak-Théron, and Nicole Asquith (eds), Policing Vulnerabilities (Federation Press, 2012) 173.

45 A 2011 study cited by Gaye Lansdell et al, “I am Not Drunk, I Have an ABI”: Findings From a Qualitative Study into Systematic Challenges in Responding to People with Acquired Brain Injuries in the Justice System' (2018) 25(5) Psychiatry, Psychology and Law 737, 737-8.

46 Cunneen et al, above n 6, 99.

47 Robin Jones and Andrew Day, 'Mental Health, Criminal Justice and Culture: Some Ways Forward?' (2011) 19 Australasian Psychiatry 325. For an in-depth examination relating to 2,731 persons in the state of NSW see Eileen Baldry et al, A Predictable and Preventable Path: Aboriginal People with Mental and Cognitive Disabilities in the Criminal Justice System (UNSW, 2015). 
and Torres Strait Islander women in prison have a diagnosed mental health condition'. ${ }^{48}$ An older study that broke this down into different types of mental conditions found that 6.6 per cent of Indigenous imprisoned males screened positive for psychosis. A further 13.1 per cent of males and 43.1 per cent of females had mood disorders and 34.4 per cent of males and 58.6 per cent of females had anxiety disorders (the most common of which was posttraumatic stress disorder). Finally, the study found that '[n]early $50 \%$ of males and over $85 \%$ of Indigenous females reported medium or higher levels of psychological distress. ${ }^{49}$

Another indicator of mental illness or distress among the prison population is the number reporting a history of self-harm or who are at risk of suicide. Upon prison entry, it has been found that 31 per cent of female entrants and 20 per cent of male entrants report a history of self-harm. When asked if they have had thoughts about harming themselves recently (in the past 12 months), the figures were 16 per cent for females and 14 per cent for males. ${ }^{50}$ People are assessed for risk of suicide or self-harm upon prison entry, with five per cent of males and three per cent of females identified as at risk. ${ }^{51}$

The World Health Organization has recognised that the nature of imprisonment is likely to worsen people's mental health if they have problems upon entry, or to cause mental health problems in some people that are healthy upon entry. This is due to factors such as the disciplinary regime, lack of choice about activities and people they spend time with, and limited communication with family and friends. ${ }^{52}$ These are aspects of daily life in Australian prisons that are outlined in more detail later in this chapter.

48 Human Rights Watch, above n 28, 22.

49 The study was conducted by Butler et al in 2001 and confirmed by Heffernan, Andersen and Kinner to be the largest study in 2009 (although they argue that there were some methodological problems with the study): Edward Heffernan, Kimina Andersen and Stuart Kinner, 'The Insidious Problem Inside: Mental Health Problems of Aboriginal and Torres Strait Islander People in Custody' (2009) 17(17) Australasian Psychiatry S41, S42-3. A study of Queensland prisoners referred to by a Senate Committee 'found that 72.8 per cent of men and 86.1 per cent of women has at least one mental health disorder': Senate Legal and Constitutional Affairs References Committee, Value of a Justice Reinvestment Approach to Criminal Justice in Australia (2013) 35.

50 Australian Institute of Health and Welfare, n 39, 43-4.

51 Ibid 47.

52 World Health Organization, Health in Prisons. A WHO Guide to the Essentials in Prison Health (2007) 134. 


\section{Disadvantaged Locations}

Prison populations in countries such as the USA, the United Kingdom (UK) and Australia are overwhelmingly drawn from a small number of locations, with Cunneen et al terming this 'imprisonment by postcode'. ${ }^{53}$ These are locations with high levels of economic and social disadvantage. The stigma associated with imprisonment, and consequent difficulty in obtaining employment and housing, has a tendency to exacerbate such disadvantage. ${ }^{54}$ It has also been observed that prison becomes normalised in such communities, to the extent where it is considered 'a near inevitability..$^{55}$

The discussions about, and trials of, justice reinvestment have significantly advanced our understanding of the over-representation of people from disadvantaged locations in the prison population. Justice reinvestment is discussed in detail in Chapter 4, but in essence it entails reallocating some of the money spent on imprisonment and investing it, in the form of social assistance, in the localities from which the majority of imprisoned people come. This includes investment in, for example, education and employment assistance programs. The way the relevant communities are identified is by 'justice mapping', which also involves assessing what services are already available in these localities. ${ }^{56}$ Justice mapping in Texas, for example, reveals that 'five counties [out of 254] ... accounted for more than half of the people imprisoned'. Further, ' 50 per cent of former prisoners returned to neighbourhoods that accounted for only 15 per cent of the Houston population'. ${ }^{57}$

The same level of detail is not available in Australian data, as noted by the Senate Legal and Constitutional Affairs References Committee during an inquiry into justice reinvestment. ${ }^{58}$ However, a study of the 'distribution of disadvantage in Australia' by Vinson compared indicators of disadvantage falling into the categories of (1) social distress, (2) health, (3) community safety, including prison admissions, (4) economic hardship

53 Cunneen et al, above n 6, 139.

54 Alison Shinkfield and Joseph Graffam, 'Community Reintegration of Ex-Prisoners' (2009) 53(1)

International Journal of Offender Therapy and Comparative Criminology 29.

55 Cunneen et al, above n 6, 143, 193.

56 David Brown, Melanie Schwartz and Laura Boseley, 'The Promise of Justice Reinvestment'

(2012) 37(2) Alternative Law Journal 96, 97.

57 Senate Legal and Constitutional Affairs References Committee, above n 49, 50.

58 Ibid 95-7. 
and (5) education, in geographic units around Australia. ${ }^{59}$ The study revealed that ' $1.7 \%$ of the geographic counting units in each jurisdiction account for seven times their share of the top ranking positions across all of the indicators'. ${ }^{60}$ A separate New South Wales (NSW) survey of people following their release from prison found that ' 50 per cent of these persons originally from the Sydney area came from and went back to just eight locations in western Sydney. ${ }^{61}$ Finally, the Victorian Ombudsman has observed that a 'quarter of Victoria's prisoners come from just 2 per cent of the State's postcodes and half from just 6 per cent'. ${ }^{62}$

In summary, socio-economic disadvantage is not evenly spread across Australia. The localities from which the prison population comes are disproportionately those that are socio-economically disadvantaged. This contributes to the concentration of socio-economic disadvantage in the prison population, which is one of the vulnerabilities discussed in the next section.

\section{Older People}

The Australian population is ageing, and the prison population is ageing at an even greater rate. The Australian Institute of Criminology defines elderly people in prison to be those over 50 years of age, which takes into account that the health of people in prison is generally worse than that of people in the general community. The health of a 50-year-old person in prison is likely to be equivalent to the health of a 60 -year-old person in the community. ${ }^{63}$

This particular group within the prison population increased by 84 per cent between 2000 and 2010, such that they comprised 11.2 per cent of the national prison population by $2011 .{ }^{64}$ The NSW statistics are illustrative and have been detailed recently by the NSW Inspector of Custodial Services who reported:

59 Tony Vinson, Dropping Off the Edge. The Distribution of Disadvantage in Australia (Jesuit Social Services/Catholic Social Services Australia, 2007) x. In some jurisdictions the 'geographic units' were Statistical Local Areas, and in others Local Government Areas.

60 Ibid xi.

61 Cunneen et al, above n 6, 141.

62 Victorian Ombudsman, Investigation into the Rehabilitation and Reintegration of Prisoners in Victoria (2015) 5.

63 Susan Baidawi et al, Older Prisoners-A Challenge for Australian Corrections (Trends and Issues in Crime and Criminal Justice No 426, 2011) 1.

64 Ibid 2. 
NSW has seen an overall increase in the prison population of 25 percent for the 10 years 2005-2015. Offenders aged over 55 increased on average 91 percent for this same period. This growth was most marked in the over 65 year olds, with elderly men increasing by approximately 225 percent and the number of elderly women increasing from three to eight percent over the last decade. ${ }^{65}$

It has also been noted that in the past 10 years, there has been a 250 per cent increase in the number of older people incarcerated in the ACT. ${ }^{66}$

The ageing of the prison population is occurring at a faster rate than the ageing of the general population. ${ }^{67}$ Explanations for the ageing prison population include sentencing laws (eg, mandatory minimum sentences and reduced options for early release) that mean people are spending longer in prison. It is also because higher proportions of older people are being convicted of offences that have longer sentences attached and due to convictions for historical sexual abuse (which has been given greater national attention recently due to the Royal Commission into Institutional Responses to Child Abuse that reported in 2017). ${ }^{68}$

\section{Vulnerabilities}

There are other characteristics of the Australian prison population that provide an important backdrop for the consideration of compliance with international human rights law in prisons. They fall into three categories: (1) general health, (2) socio-economic status and (3) the specific vulnerabilities of women.

65 NSW Inspector of Custodial Services, Old and Inside: Managing Aged Offenders in Custody (2015) 16. For another report relating to NSW see Chris Angus Older Prisoners: Trends and Challenges (NSW Parliamentary Research Service, 2015).

66 ACT Inspector of Correctional Services, Report of a Review of a Correctional Centre by the ACT Inspector of Correctional Services Healthy Prison Review of the Alexander Maconochie Centre (2019) 98.

67 Statistics about the general population 'show that the numbers of Australians aged 50 years and over increased by 31 percent over the period 2000-10, comparatively smaller than the 84 percent increase observed in the older prisoner population over the same period': Baidawi, above n 63 .

68 Ibid 2-3; NSW Inspector of Custodial Services, above n 65, 16; ACT Inspector of Correctional Services, above n 66, 98. 


\section{General Health}

In addition to the mental health and disability rates outlined above, imprisoned people as a group tend to have poor overall health when compared to the general population. This contributes to them being classified as 'elderly' at a younger age than people in the wider community. The Australian Institute of Health and Welfare provides the following snapshot:

Prisoners have higher levels of mental health problems, risky alcohol consumption, tobacco smoking, illicit drug use, chronic disease and communicable diseases than the general population. This means that prisoners have significant and complex health needs, which are often long-term or chronic in nature. The health of prisoners is sufficiently poorer than in the general community such that prisoners are often considered to be geriatric at the age of 50-55. ${ }^{69}$

Drug and alcohol addiction feature prominently among the prison population and at much higher rates than among the general community (three times higher for men and six times higher for women ${ }^{70}$ ):

- 65 per cent of imprisoned people have used illicit drugs in the 12 months prior to their incarceration ${ }^{71}$

- 46 per cent have injected drugs ${ }^{72}$

- 34 per cent of prison entrants were found to be at risk of a high level of alcohol-related harm in the past 12 months. $^{73}$

Smoking is another relevant addiction, with 75 per cent of people entering prison identifying as smokers. ${ }^{74}$ This compares to the national average of 12.2 per cent. ${ }^{75}$ This is not surprising given the over-representation in

69 References contained in the original quotation are excluded. Australian Institute of Health and Welfare, The Health of Australian Prisoners 2015 (2015) 2.

70 Australian Institute of Health and Welfare, above n 39, 97.

71 Ibid 92.

72 Ibid 95 .

73 Ibid 101. The same report notes the following about how this assessment is made: 'The proportion of prison entrants who are at risk of alcohol-related harm was determined using questions on alcohol consumption from the WHO's Alcohol Use Disorder Identification Test (AUDIT) screening instrument. The consumption component of this instrument (AUDIT-C) contains the three consumption questions from the AUDIT, with each question scoring $0-4$. Scores for the three questions are summed, with a maximum possible score of 12 . A score of 6 or more indicates a risk of alcohol-related harm.': at 101 . 74 Ibid 85.

75 Australian Institute of Health and Welfare, National Drug Strategy Household Survey 2016 Detailed Findings (2017) 7. 
prison of sub-groups (eg, those with a mental illness, illicit drug users and Indigenous people) that have a high incidence of smoking generally. The Australian Institute of Health and Welfare has found:

- 'people who reported smoking daily were ... twice as likely to have been diagnosed with, or treated for, a mental health condition as those who had never smoked (29\% compared with $12.4 \%)^{776}$

- 27 per cent of Indigenous Australians are smokers ${ }^{77}$

- 28 per cent of illicit drug users smoke. ${ }^{78}$

An example of communicable disease is the prevalence of Hepatitis $\mathrm{C}$ among the prison population, which stands at 31 per cent nationally. ${ }^{79}$ A study of Hepatitis C transmission in Australian prisons found that the highest rate, 42 per cent, was in NSW and the lowest, 21 per cent, was in Western Australia. The Indigenous rate was higher, at 43 per cent, than the non-Indigenous rate of 33 per cent. ${ }^{80}$ There is evidence that being incarcerated increases the chances of contracting Hepatitis C. A NSW study, for example, found that one in three injecting drug users in prison contracted the disease. ${ }^{81}$

\section{Socio-Economic Status}

Relevant socio-economic indicators for the prison population, as identified by the Australian Institute of Health and Welfare, include poor levels of education, low levels of employment, high levels of homelessness and a significant proportion of people who have a parent who had also been imprisoned.

76 Ibid 113. As an illustration, 68 per cent of patients at the Thomas Embling Hospital in Victoria (a secure mental health facility) identified as smokers in a 2013 survey: Robert Peter De Bruyn v Victorian Institute of Forensic Mental Health [2016] VSC 111, [32].

77 Ibid 105. These rates are higher in some jurisdictions. For example, in the Northern Territory, 66 per cent of Indigenous males and 47 per cent of Indigenous females are smokers: Marita Hefler, Robyn Hopkins and David Thomas, 'Successes and Unintended Consequences of the Northern Territory's Smoke-Free Prisons Policy: Results From a Process Evaluation' (2016) 26(2) Public Health Research and Practice 1, 2.

78 Ibid 9.

79 Australian Institute of Health and Welfare, above n 69, 55.

80 Jack Wallace et al, Regulating Hepatitis C: Rights and Duties. Preventing Hepatitis C Transmission in Australian Adult Correctional Settings (La Trobe University, 2009) 9.

81 Kate Dolan et al, 'Incidence and Risk for Acute Hepatitis C Infection During Imprisonment in Australia' (2010) 25 European Journal of Epidemiology 2. 


\section{Education}

It has been found that 33 per cent of Australian prison entrants have not completed Year 10, with 17 per cent of those having completed year 8 or below'. ${ }^{82}$ Indigenous people entering prison are more likely to have completed 'year 8 or below' with the proportion being 24 per cent. ${ }^{83}$ The comparisons the Australian Institute of Health and Welfare make with the general community are broken down by age group. For instance, of people aged between 25 and 34, 24 per cent of non-Indigenous prison entrants and 21 per cent of Indigenous prison entrants have completed only Year 10 or below, compared to 17 per cent of the non-Indigenous and 2 per cent of Indigenous people in the general population. ${ }^{84}$

The Australian Institute of Health and Welfare go on to report that ' $[\mathrm{b}]$ oth Indigenous (2-4\%) and non-Indigenous (6-11\%) prison entrants aged 20-44 were less likely than their general community counterparts to have completed Year 12 or equivalent (10-26\% and $13-36 \%$ respectively)' ${ }^{85}$

\section{Employment}

In the 30 days prior to incarceration, 67 per cent of Indigenous and 50 per cent of non-Indigenous entrants report being unemployed ${ }^{86}$ Approximately 29 per cent of prison entrants report having 'a chronic condition or disability that affected their participation in day-to-day activities', with 22 per cent of females and 15 per cent of males reporting that this impacted on their employment. ${ }^{87}$

\section{Homelessness}

The Australian Institute of Health and Welfare has found that '[p]rison entrants were around 66 times more likely to be homeless than people in the general community ${ }^{88}$ In the four weeks prior to incarceration,

82 Australian Institute of Health and Welfare, above n 39, 16. Note that the Australian Institute of Health and Welfare does not provide a breakdown of the education levels for male and female prison entrants.

83 Ibid 17.

84 Australian Institute of Health and Welfare, above n 69, 23. The comparative data is from the earlier Australian Institute of Health and Welfare report because the 2019 report only provides the comparison for tertiary studies.

85 Ibid.

86 Ibid 18.

87 Ibid 78. See also Figure 9.1: ibid 79.

88 Ibid 22. 
5 per cent of prison entrants were 'in unconventional housing or sleeping rough', and 37 per cent of Indigenous entrants and 23 per cent of nonIndigenous entrants were in 'short-term/emergency accommodation'. ${ }^{89}$

\section{Parental Imprisonment}

The high proportion of people in prison with a parent who had been incarcerated when they were children reveals an inter-generational trend in imprisonment. The stigma and disruption of having a parent incarcerated has social and emotional consequences for children, causing social disadvantage. ${ }^{90}$ Eighteen per cent of prison entrants 'reported that 1 or more of their parents or carers had been in prison during their childhood'. ${ }^{91}$ The figures for Indigenous prison entrants were higher, with 31 per cent of Indigenous entrants and 11 per cent of non-Indigenous entrants reporting this as their situation..$^{92}$

\section{Women's Vulnerability}

It has been established in the preceding discussion that women represent a rapidly growing segment of the Australian prison population, particularly Indigenous women. They also have higher levels of mental illness than male prison entrants and the male levels are disproportionately higher than the general population.

There are some further vulnerabilities specific to women imprisoned in Australia that it is important to emphasise. These are the high rates of victimisation and the high proportion of women who are primary caregivers for dependent children. When these are combined with the higher rates of mental illness, it leads to the conclusion that ' $[\mathrm{t}]$ he prevalence of histories of abuse and violence and the experience of multiple and complex support needs among women in prison can no longer be overlooked as somehow exceptional or marginal'. ${ }^{93}$

89 Ibid. See also Figures 2.8 and 2.9: ibid 23.

90 See, eg, Alannah Burgess and Catherine Flynn, 'Supporting Imprisoned Mothers and Their Children. A Call for Evidence' (2013) 60(1) Probation Journal 73.

91 Australian Institute of Health and Welfare, above n 39, 14.

92 Ibid.

93 Ruth McCausland and Eileen Baldry 'Understanding Women Offenders in Prison' in Jane Ireland et al (eds), The Routledge International Handbook of Forensic Psychology in Secure Settings (Routledge, 2017) 32. 
A national study estimated that between 57 and 90 per cent of women in prison have been victims of childhood sexual abuse. ${ }^{94}$ More recent data from Queensland suggests that 37 per cent have been victims of abuse before they turn 16 and 35 per cent before they turn $10.9^{95}$

These rates are even higher among Indigenous women. The Australian Law Reform Commission provides the following up-to-date summary of the research:

Prison population surveys have revealed high rates of family violence and sexual abuse among incarcerated Aboriginal and Torres Strait Islander women. One Western Australian study suggested that up to $90 \%$ of Aboriginal and Torres Strait Islander female prisoners were survivors of family and other violence. A New South Wales study in 2014 revealed that $70 \%$ of the Aboriginal and Torres Strait Islander female prisoners disclosed they were survivors of child sexual abuse, with $44 \%$ subject to ongoing sexual abuse as adults and $78 \%$ experiencing violence as adults. ${ }^{96}$

A number of monitoring bodies have recognised the traumatic impact that standard prison practices-particularly strip searching — can have on women with this history. For example, the Queensland Ombudsman wrote in an investigation of strip searching at the Townsville Women's Correctional Centre that 'research also suggests that, due to the high levels of past sexual abuse among female prisoners, strip searches have the capacity to negatively impact (including re-traumatise) female prisoners more significantly than other parts of the population and may jeopardise attempts at rehabilitation'. ${ }^{97}$ The Victorian Ombudsman has also criticised the practice at the Dame Phyllis Frost Centre, reporting:

this humiliating, degrading and undignified practice persists, described by some women prisoners as a form of sexual assault. It should not be forgotten that many women prisoners are victims of sexual abuse, for whom strip searching has the potential to inflict further trauma..$^{98}$

94 Mary Stathopoulos, 'Addressing Women's Victimisation in Custodial Settings' (ACSSA Issues No 13, Australian Institute of Family Studies Australian Centre for the Study of Sexual Assault, 2012) 4.

95 Anti-Discrimination Commission Queensland, Women in Prison (2017) 72.

96 Australian Law Reform Commission, above n 36, 351.

97 Queensland Ombudsman, The Strip Searching of Female Prisoners Report. An Investigation into the Strip Search Practices at Townsville Women's Correctional Centre (2014) 5.

98 Victorian Ombudsman, Implementing OPCAT in Victoria: Report and Inspection of the Dame Phyllis Frost Centre (2017) 5. See also Anti-Discrimination Commission Queensland, above n 95, 72-3; ACT Human Rights and Discrimination Commissioner, Human Rights Audit on the Conditions of Detention of Women at the Alexander Maconochie Centre (2014) 68-9. 
Two-thirds of women sentenced to imprisonment are primary caregivers for dependent children. ${ }^{99}$ These children have to be cared for by relatives during their mother's incarceration, or are taken into the care of the state. Being in prison has a well-recognised differential impact on mothers, with Burgess and Flynn explaining that ' $\mathrm{t}]$ hese pre-existing vulnerabilities are further compounded by experiences during the prison sentence, which can negate women's role and confidence as mothers, leading to mental health concerns and fear that they will lose their children's love' ${ }^{100}$

\section{Concluding Remarks on the Australian Prison Population Profile}

The prison population in Australia is increasing, but it is not representative of the broader community. Particular sub-groups, including Indigenous people, women and mentally ill people, are over-represented. This combines with other socio-economic disadvantage and health problems to mean that the prison population is comprised of the most vulnerable and marginalised members of the community. ${ }^{101}$ Put another way, those sent to prison are more likely to be disadvantaged in one or more ways and those already disadvantaged groups are becoming increasingly likely to be imprisoned.

The causal factors generating Australia's prison population profile are complex and extend beyond penal policies. They include:

- harsh sentencing policies that lead to increased use of imprisonment and longer sentences ${ }^{102}$

- over-policing of Indigenous communities ${ }^{103}$

99 Burgess and Flynn, above $\mathrm{n} 90,74$.

100 Ibid. The impact of parental incarceration on children is explored in depth in a special issue of Law in Context edited by Anna Eriksson and Catherine Flynn (2015) 32.

101 Jill Guthrie, Michael Levy and Cressida Forde, 'Investment in Prisons: An Investment in Social Exclusion. Linking the Theories of Justice Reinvestment and Social Inclusion to Examine Australia's Propensity to Incarcerate' (2013) 1(2) Griffith Journal of Law \& Human Dignity 254, 263.

102 Such as the 'tough on crime' sentencing reforms introduced in Victoria: Michelle McDonnell and James Farrell, 'Tough, Tougher, Toughest? A New Government's Approach to Sentencing Laws in Victoria' (2012) 37(3) Alternative Law Journal 238, 242.

103 Indigenous people are ' 22 times more likely to be arrested or detained by police than nonIndigenous people': Lorana Bartels, 'Twenty Years On: Indigenous Deaths in Police Custody and Lessons from the Frontline' in Isabelle Bartkowiak-Théron and Nicole Asquith (eds), Policing Vulnerabilities (Federation Press, 2012) 181. 
- lack of support and community treatment programs for people with mental illness and disabilities ${ }^{104}$

- the changing prevalence of certain types of crimes (although, as noted above, the overall crime rate is not increasing). ${ }^{105}$

The complex vulnerabilities of the Australian prison population, combined with their experiences of daily life in prison that are discussed in the remainder of this chapter, provide compelling justification for the human rights protections examined by the remainder of this book.

\section{Sociological Literature: Daily Life in Australian Prisons}

Two studies are considered here. The first is Goffman's characterisation of prisons as a 'total institution', and the second is Sykes's formulation of the 'pains of imprisonment'. ${ }^{106}$ Both of these classic sociological analyses date from the 1950s and 1960s, yet continue to provide a pertinent framework for understanding the lives of people in prison. ${ }^{107}$ Neither was written in an Australian context, but Australian statistical data is employed to demonstrate their relevance to contemporary Australian prisons.

\section{Total Institution}

The prison environment is heavily controlled. Every aspect of people's lives is regulated, including when they can leave their cell, when they can access showers and toilets (in cases where neither are in their cell), and when they eat. Their access to medical services is also regulated, as is what

\footnotetext{
104 In relation to mental illness see chapters 8 and 9 of Senate Select Committee on Mental Health, A National Approach to Mental Health - From Crisis to Community, First Report (2006) Chapters 8-9; Guthrie, Levy and Forde, above n 101, 265. In relation to disabilities see Productivity Commission, Disability Care and Support, Productivity Commission Inquiry Report (2011) Chapter 2.

105 See, eg, the Victorian Sentencing Advisory Council discussion of increases in 'offences against the person, drug offences and offences against good order': Sentencing Advisory Council, above n 18, 36. 106 Erving Goffman, Asylums. Essays on the Social Situation of Mental Patients and Other Inmates (Aldine Publishing Company, 1962); Gresham Sykes, Society of Captives; A Study of a Maximum Security Prison (Princeton University Press, 1958).

107 In 2001, Sykes's Society of Captives was held to be the top ranked of the three most influential books in penology in the twentieth century: Michael Reisig, 'The Champion, Contender, and Challenger: Top-Ranked Books in Prison Studies' (2001) 81(3) The Prison Journal 389. Goffman's 1961 book Asylums is still being printed: Seamus Mac Suibhne, 'Erving Goffman's Asylums 50 Years On' (2011) 198 The British Journal of Psychiatry 1, 1.
} 
they may possess, when they can communicate with other people (both within and outside the prison), and their participation in activities such as work and education.

\section{Definition}

It is the regulated nature of the environment that led Goffman to characterise prisons as 'total institutions', which he defines as having the following characteristics:

First, all aspects of life are conducted in the same place and under the same single authority. Second, each phase of the member's daily activity is carried on in the immediate company of a large batch of others, all of whom are treated alike and required to do the same thing together. Third, all phases of the day's activities are tightly scheduled, with one activity leading at a prearranged time into the next, the whole sequence of activities being imposed from above by a system of explicit formal rulings and a body of officials. Finally, the various enforced activities are brought together into a single rational plan purportedly designed to fulfil the official aims of the institution. ${ }^{108}$

According to Goffman, when someone enters a prison, they undergo the processes of 'role stripping' and 'mortification', which in essence involves the loss of the role the individual had in society, and a loss of personal autonomy and privacy. As Van Zyl Smit and Snacken explain in relation to contemporary European prisons, these processes begin during the induction procedures when personal effects and clothing are confiscated, people are strip searched and they are given a uniform. The same processes are then reinforced by daily occurrences, such as correspondence being inspected, cells being searched and other security procedures. ${ }^{109}$ In addition to these physical elements, there is the requirement for people to mix with others whether they want to or not, something Goffman argues 'can lead an inmate to feel he [sic] is being contaminated by contact with undesirable fellow inmates'. 110

108 Goffman, above n 106, 6. He also classifies other institutions, such as mental institutions, army barracks, aged care homes and boarding schools, as 'total institutions': at 4-5.

109 Dirk Van Zyl Smit and Sonja Snacken, Principles of European Prison Law and Policy. Penology and Human Rights (Oxford University Press, 2009) 39. See also ibid 14-35.

110 Goffman, above n 106, 29. 


\section{Implications of the 'Total Institution'}

There are a number of implications of the 'total institution' aspect of prisons that are relevant to compliance with international human rights law in prisons. The three discussed here are the loss of personal autonomy, abuse of power, and powerlessness caused by rules and disciplinary proceedings. Specific examples of the implications of the 'total institution' on the requirement that imprisoned people be treated with humanity and respect are provided in Chapter 7.

\section{Loss of Personal Autonomy}

People lose their ability to make everyday decisions, particularly those that allow them to behave in the way they would when not in prison. Examples of this have occurred in Australian prisons and three of these are as follows. First, an imprisoned person who was of Muslim faith was provided with a vegetarian diet for four months despite the fact that other imprisoned people were provided with halal meat. The person in question was told that halal meat was unavailable. ${ }^{111}$ Second, remandees were being woken at 6.00 am daily to be transported to court for their hearing. Transport involved their confinement for between 65 and 80 minutes in small compartments in a prison transport van. ${ }^{112}$ Medical evidence was provided to the court that this routine was causing 'psychological and emotional difficulties' and fatigue, and that it was affecting their ability to concentrate and remember things. ${ }^{113}$ The Court was satisfied on the basis of this evidence that the accused were unable to participate effectively in their trial, making it an unfair trial. ${ }^{114}$ Third, people in Tasmanian prisons were being issued with inadequate amounts of underwear and socks (two pairs of each) upon their arrival in prison that had also previously been used by other people. The Tasmanian Custodial Inspector wrote of this situation, ' $\mathrm{i}] \mathrm{t}$ is not considered acceptable for prisoners to wear previously used underwear, even if it has been freshly washed'. ${ }^{115}$

111 Ali v State of Queensland [2013] QCAT 319 (6 August 2013). The Tribunal awarded Mr Ali $\$ 3,000$ compensation.

112 R v Benbrika \& Ors (Ruling No 20) (2008) 18 VR 410 [34]-[35].

113 Ibid [82]-[84].

114 Ibid [91]. See also the discussion in Bronwyn Naylor, 'Protecting the Human Rights of Prisoners in Australia' in Paula Gerber and Melissa Castan (eds), Contemporary Perspectives on Human Rights Law in Australia (Lawbook Co, 2013) 407; Rebecca Ananian-Walsh, 'A Fair Trial for Accused Terrorists' in Matthew Groves, Janina Boughey and Dan Meagher (eds), The Legal Protection of Rights in Australia (Bloomsbury Publishing, 2019).

115 Tasmanian Custodial Inspector, Inspection of Adult Custodial Services in Tasmania, 2017 Care and Wellbeing Inspection Report (October 2018) 29. 
Some international examples include laundry processes being organised in such a manner that people did not have their own underwear and socks returned to them, and people being forced to use a bucket overnight when they did not have access to a toilet (in many cases in the presence of their cell mate). ${ }^{116}$

A corollary of loss of autonomy is lack of control over, or choice about, who to associate with. This has serious implications for the right to security of the person and the right to freedom of association. Prisons are designed to house members of the community who pose a danger to others. Therefore, it is logical to assume that many of these people also pose a danger to one another (although this is not to suggest that every person in prison represents a danger to others). The risk of violence and harassment is more acute for people who have been convicted of particular offences, such as child sexual abuse. ${ }^{117}$ In the case of sexual violence in male prisons, those who are young, those who are perceived to have 'feminine characteristics' and those who are transgender are particular targets. ${ }^{118}$ The lack of control over who to share a cell with, and who to associate with on a daily basis, means that people cannot protect themselves from the risk of violence. This poses a threat to the right to security of the person. This theme is developed further in the next section because two of the 'pains of imprisonment' identified by Sykes are deprivation of autonomy and security.

\section{Abuse of Power}

Due to the hierarchical nature of 'total institutions', imprisoned people are at risk of abuse of power by staff. This may be either physical or psychological, although it is important to emphasise that not all staff abuse their power. Some staff may hold preconceived views about how punitive the prison environment should be, which tends to lead to staff behaviour that is lacking in respect. ${ }^{119}$ Some Australian examples of this include:

116 Her Majesty's Inspectorate of Prisons, Report on HMP Aberdeen Full Inspection 6 - 10 October 2008 (2009) 8 [2.29]; Independent Monitoring Boards, 'Slopping Out?' A Report on the Lack of In-Cell Sanitation in Her Majesty's Prisons in England and Wales (National Council for Independent Monitoring Boards, 2010).

117 Dot Goulding, 'Violence and Brutality in Prisons: A West Australian Context' (2007) 18(3) Current Issues in Criminal Justice 399, 407.

118 Richard Edney, 'To Keep Me Safe From Harm? Transgender Prisoners and the Experience of Imprisonment' (2004) 9(2) Deakin Law Review 327, 332. See also Sam Lynch and Lorana Bartels, 'Transgender Prisoners in Australia: An Examination of the Issues, Law and Policy' (2017) 19 Flinders Law Journal 185, 193-4 (mainly referring back to Edney's article).

119 One study found that 61 per cent of prison officers in California consider that the goal of prison should be 'totally punishment': Amy Lerman and Joshua Page, 'The State of the Job: An Embedded Work Role Perspective on Prison Officer Attitudes' (2012) 14(5) Punishment \& Society 503, 516. Australian prison staff attitudes are discussed in detail in Chapter 7. 
- the South Australian policy of shackling people to their hospital beds during treatment, including during end-of-life care and childbirth ${ }^{120}$

- the case of Mr Brough who, as a 16-year-old intellectually disabled Indigenous person, was held in an adult correctional centre in a padded isolation cell with the lights on continuously and, for periods, without any clothes ${ }^{121}$

- Mr Eastman's allegation that he was subjected to verbal abuse by staff in the Alexander Maconochie Centre in the ACT, by, for example, being called 'murderer' and 'idiot'. ${ }^{122}$

People in prison themselves hold varying degrees of informal power. Research about the culture in prisons suggests that hierarchies often form among the population of those who are imprisoned. This leads to increased vulnerability for those at the bottom of the hierarchy (and, as noted above, these people tend to be at most risk of violence). People known as 'prison heavies' have the most power within this hierarchy and tend to be the most violent and feared by others. People in protection units tend to be the least powerful and the most targeted. As one Western Australian imprisoned person commented in an interview, 'when you're in protection you're targeted by mainstream prisoners because they think we're all tramps (paedophiles). So we have to go places like the library or canteen all together on a Friday to cut down the risk of assault'. ${ }^{123}$

\section{Powerlessness}

People in a 'total institution' are subject to a multitude of rules that must be followed, and the disciplinary proceedings that result from failure to comply with these rules. In many instances, these rules may serve as a protection from human rights violations-for example, they prohibit people from assaulting prison staff and other imprisoned people.

However, rule violations can lead to restrictions being imposed that circumscribe rights. Two examples are: (1) denial of visits from family members, which may contradict the protections put in place for the family, including the prohibition against 'arbitrary or unlawful interference'

120 Ombudsman South Australia, Ombudsman Investigation into the Department of Correctional Services in Relation to the Restraining and Shackling of Prisoners in Hospitals (2012).

121 Human Rights Committee, Views: Communication No 1184/2003, UN Doc CCPR/C/86/D/ 1184/2003 (17 March 2006) ('Brough v Australia').

122 Eastman $v$ Chief Executive of the Department of Justice and Community Safety [2011] ACTSC 33 (4 March 2011) [26]-[40].

123 Goulding, above n 117, 407. 
with family and correspondence; ${ }^{124}$ and (2) placing people in solitary confinement for prolonged periods, which can lead to violations of arts $10(1)$ and 10(3) of the ICCPR, as occurred in the case of Mr Brough (mentioned briefly above and discussed in more depth in Chapter 2).

It is also problematic when an imprisoned person neither understands the rules they are subject to, nor the behaviour that is contrary to those rules. This is quite likely in light of the statistics about the prevalence of cognitive disability in the prison population discussed in the first half of this chapter. A relevant example is provided by Owers, who notes, 'when I met a young man with severe learning difficulties and asked how he got to know what the rules of the prison were - "If I get sent down the block, I know I've broken a rule" was the response'. ${ }^{125}$

Such penalties will often be justified for security reasons, but there is also a balance that needs to be achieved between maintenance of security and protection of human rights. The balance is often tipped in favour of security. Critical assessments need to be made about whether this is in fact justified. As Owers warns, 'security can come to have the quality of the parental "because I say so"; the trump card, the excuse rather than the reason'. ${ }^{126}$ While ever security remains the 'trump card' in Australian prisons, it will not be possible to achieve human rights compliance. ${ }^{127}$

\section{Pains of Imprisonment}

The other main sociological study of significance to this book is by Sykes, who sought to understand prison social structures. His work highlights that the prison's 'brutalising effects bound prisoners to a common identity, displaced their prior identities, and socialised them almost irresistibly into roles and values that would remain consistent whoever entered the milieu'. ${ }^{128} \mathrm{He}$ was writing in a time when (officially) the

124 Articles 17 and 23 of the International Covenant on Civil and Political Rights, opened for signature 19 December 1966, 999 UNTS 171 (entered into force 23 March 1976), which are reflected in ss 13 and 17 of the Charter of Human Rights and Responsibilities Act 2006 (Vic), ss 11 and 12 of the Human Rights Act 2004 (ACT) and s 25 of the Human Rights Act 2019 (Qld).

125 Anne Owers, 'Comparative Experiences of Implementing Human Rights in Closed Environments: Monitoring for Rights Protection' in Bronwyn Naylor, Julie Debeljak and Anita Mackay (eds), Human Rights in Closed Environments (Federation Press, 2014) 221.

126 Anne Owers, 'Prison Inspection and the Protection of Human Rights' (2004) 2 European Human Rights Law Review 107, 109.

127 The emphasis on security in legislation governing Australian prison management is detailed in Chapter 5.

128 Ben Crewe, 'Gresham Sykes' in Keith Hayward, Shadd Maruna and Jayne Mooney (eds), Fifty Key Thinkers in Criminology (Routledge, 2010) 136-7. 
focus of imprisonment had moved away from the imposition of physical discipline, noting that 'severe bodily suffering has long since disappeared as a significant aspect of the custodians' regime'; ${ }^{129}$ rather, the suffering people experience is psychological. He argued that such suffering may be categorised into the deprivation of all of the following: (1) liberty, (2) goods and services, (3) heterosexual relationships, (4) autonomy and (5) security. These 'pains of imprisonment' are all evident in Australian prisons.

It should be noted that Sykes's 'pains of imprisonment' are still being used in empirical studies of the sociology of imprisonment. A 2017 edited collection entitles the second part 'coping with the pains of imprisonment', which is introduced with an overview of Sykes's five pains of imprisonment as listed above. ${ }^{130}$ Crewe has suggested that there are additional pains evident in prisons in the UK, and Shammas, building on Sykes's work, has argued that an open prison in Norway subjects residents to what he terms the 'pains of freedom'. ${ }^{131}$ This demonstrates the ongoing relevance of Sykes's formulation.

\section{Deprivation of Liberty}

Sykes observed that the 'loss of liberty is a double one-first, by confinement to the institution and second, by confinement within the institution'. ${ }^{132}$ This means that people in prison are both unable to leave the prison, and are also unable to freely move about the prison. They are often confined to their cell and do not have any choice about when they access other parts of the prison, such as the common room, outside areas or medical services. This is a feature of the prison as a 'total institution'. This is definitely evident in Australian prisons where the national average of time spent out of cells is nine hours per day, and where, in some jurisdictions, it is less (eg, 7.2 hours per day in NSW and 7.7 hours in Tasmania and South Australia). ${ }^{133}$

129 Sykes, above n 106, 64 .

130 Carla Reeves (ed), Experiencing Imprisonment. Research on the Experience of Living and Working in Carceral Institutions (Routledge, 2017) 115-18. A report by the NSW Inspector of Custodial Services also makes a reference to Sykes: NSW Inspector of Custodial Services, Report No. 1 - The Invisibility of Correctional Officer Work (2014) 25.

131 Crewe, above n 128. Victor Shammas, 'The Pains of Freedom: Assessing the Ambiguity of Scandinavian Penal Exceptionalism on Norway's Prison Island' (2014) 16(1) Punishment \& Society 104.

132 Sykes, above n 106, 65.

133 These figures are for secure prisons. Steering Committee for the Review of Government Service Provision (2019), above n 21, Table 8A.13. 
Sykes's view of deprivation of liberty also encompasses the deprivation of contact with family members and friends. In addition to limited faceto-face contact, this includes restrictions on phone calls and written contact. ${ }^{134}$ It is a common complaint of people in Australian prisons that their contact with people outside the prison is circumscribed, with even the face-to-face contact that does occur bound by rules about no physical contact. ${ }^{135}$ This has been a particular issue in relation to funeral attendance in Western Australia. ${ }^{136}$

Further, as Sykes argues, this pain includes the fact that incarceration 'represents a deliberate, moral rejection of the criminal by the free community'. ${ }^{137}$ Even though Australian law has abandoned the concept of 'civil death', imprisoned people still lose fundamental elements of citizenship, including the right to vote, if they are sentenced to longer than three years of imprisonment. ${ }^{138}$

\section{Deprivation of Goods and Services}

In the prison environment, people are generally not allowed to wear their own clothes, they are provided with furnishings for their cell not of their own choosing, they do not have much control over what they eat or when they exercise, and particular goods (eg, cigarettes and alcohol) are restricted or banned. ${ }^{139}$

Sykes notes that due to the disadvantaged background of many people in prisons (as is evident in the Australian prison population from the discussion in the first part of this chapter), some may argue that they are better off in prison than they would be in the community. However, Sykes emphasises that the pains of imprisonment are to be considered from the perspective of imprisoned people rather than by objective measures, and he notes that 'legitimately or illegitimately, rationally or irrationally, the inmate population defines its present material impoverishment as a painful loss'. ${ }^{140}$

134 Sykes, above n 106, 65.

135 Bronwyn Naylor, 'Human Rights and Respect in Prisons: The Prisoners' in Bronwyn Naylor, Julie Debeljak and Anita Mackay (eds), Human Rights in Closed Environments (Federation Press, 2014) 101. See generally Office of the Inspector of Custodial Services (OICS), Contact with Family and Friends While in Custody (2018).

136 OICS, Funeral Attendances by Incarcerated People in Western Australia (2013).

137 Sykes, above n 106, 65.

138 Naylor, above n 114, 395-6. A position upheld by the High Court in Roach $v$ Electoral Commissioner (2007) 233 CLR 162. This decision is discussed in Chapter 5.

139 Sykes, above n 106, 68.

140 Ibid. 
A good example of this 'pain of imprisonment' in the Australian context is access to cigarettes, something that is of great significance to most people in prisons given that, as noted earlier in this chapter, 75 per cent of people entering prison identify as smokers. ${ }^{141}$ Smoking has been described as 'one of the few social pleasures not denied to prisoners', yet this is rapidly changing. ${ }^{142}$ Smoking has been banned in prisons in the majority of Australian states and territories, with the Northern Territory becoming the first to ban smoking from 1 July 2013. ${ }^{143}$ Queensland, NSW, Victoria, Tasmania and South Australia have followed suit. ${ }^{144}$ This leaves the ACT and Western Australia as the only jurisdictions without smoking bans in prisons. ${ }^{145}$

The general effectiveness of such bans is debatable, ${ }^{146}$ and an investigation into a riot in Victoria in 2015 found that the introduction of the smoking ban had been the 'catalyst' (although there were other contributing factors). ${ }^{147}$ However, the mere fact that bans are being imposed exemplifies the loss of access to goods in the prison environment that is likely to cause people pain. In this instance, it is more than psychological pain, as the physical symptoms of nicotine withdrawal may ensue. As a New Zealand judge commented in the context of the smoking bans imposed in New Zealand prisons, '[ $\mathrm{f}$ ]orcing prisoners into nicotine withdrawal is not humane. ${ }^{148}$

141 Australian Institute of Health and Welfare, above n 39, 85.

142 OICS, Issues Paper. Smoking in Prison (2008) 3.

143 Hefler, Hopkins and Thomas, above n 77, 1.

144 Anita Mackay, 'The Human Rights Implications of Smoking Bans in Closed Environments: What Australia May Learn From the International Experience' (2016) 46 International Journal of Law, Crime and Justice 13, 14; Premier of South Australia, 'All SA Prisons Successfully Transition to Smoke Free' (Media Release, 26 February 2020).

145 The ACT Drug Strategy Action Plan 2018-2021 released in December 2018 contained the following 'action' about smoking in the prison in the ACT: 'Deliver a comprehensive strategy that will describe actions to be undertaken to address alcohol, tobacco and drug and blood borne viruses issues in ACT correctional centres until 2022'. This was assigned to the ACT Health Directorate: ACT Government, ACT Drug Strategy Action Plan 2018-2021: A Plan to Minimise Harms from Alcohol, Tobacco and Other Drug Use (2018) 28. A 2019 review by the ACT Inspector of Correctional Services raised concerns about smokers and non-smokers being required to share cells: above n 66, 107.

146 See Anita Mackay, 'Stubbing Out Smoking in Prisons. Bans are an Ineffective Mechanism' (2014) 39(2) Alternative Law Journal 99; Hefler, Hopkins and Thomas, above n 77.

147 Independent Investigation into the Metropolitan Remand Centre Riot, Final Report (December 2015) 6. There have also been other riots associated with the introduction of smoking bans: see Mackay, above n 146, 20.

148 Taylor v The Attorney-General and Ors [2013] NZHC 1659 (3 July 2013) [31]. Mr Taylor also brought a landmark case about the voting rights of imprisoned people in New Zealand: AttorneyGeneral v Taylor [2018] NZSC 104 (9 November 2018). 


\section{Deprivation of Heterosexual Relationships}

There are two aspects to this particular 'pain of imprisonment', which is based on Sykes's observations in an all-male prison. The first is the denial of the ability to have heterosexual intercourse, which Sykes writes 'is a frustration which weighs heavily and painfully' on people's minds while incarcerated. ${ }^{149}$ The second is the lack of contact with women, which impacts on people's identity. Sykes argues that 'since a significant half of his audience is denied him, the inmate's self-image is in danger of becoming half complete, fractured, a monochrome without the hues of reality'. ${ }^{150}$

There has not been much research conducted about sex in Australian prisons. However, a large telephone survey of imprisoned males was conducted in 2007 in Queensland and NSW prisons as part of the 'Sexual Health and Attitudes of Australian Prisoners Study'. ${ }^{151}$ This study found that a similar proportion of imprisoned people report being heterosexual (95.7 per cent) as in the general community ( 97.4 per cent), but that imprisoned people were more likely to disapprove of sex between men (62 per cent) than those in the community (37 per cent). ${ }^{152}$ The study also found that ' $[\mathrm{o}] \mathrm{f}$ those who identified as heterosexual, $79.5 \%$ of men and $73.9 \%$ of women had a regular opposite-sex partner just before prison'. ${ }^{153}$ Further, there is strong support among the imprisoned population for overnight visits from spouses and partners (89.5 per cent of men and 77.2 per cent of women), which is generally not allowed in Australian prisons. ${ }^{154}$ This supports Sykes's contention that deprivation of heterosexual sex is likely to be a 'pain of imprisonment' among the Australian prison population.

149 Sykes, above n 106, 71.

150 Ibid 72.

151 The survey covered 14 per cent of the male prison population in 2007: Juliet Ritchers et al, 'Consensual Sex Between Men and Sexual Violence in Australian Prisons' (2012) 41 Archives of Sexual Behavior 517, 518-19.

152 Tony Butler et al, 'Sexual Behaviour and Sexual Health of Australian Prisoners' (2013) 10 Sexual Health 64, 66; ibid 523.

153 Butler et al, above n 152, 66.

154 Eva Malacova, 'Attitudes Towards Sex: A Comparison of Prisoners and the General Community' (2011) 8 Sexual Health 355, 359. Overnight visits are, however, allowed in four Victorian prisons: Corrections Victoria, Deputy Commissioner's Instruction No: 3.04 'Visits: - Personal - ProfessionalAdult Parole Board'; Naylor, above n 135, 103. 
No research could be located about the problems for identity associated with men having little contact with women in Australian prisons. This particular aspect of this pain of imprisonment may have reduced somewhat since the time Sykes was writing, given that male prisons employ female staff members. ${ }^{155}$

The threat, and incidence, of sexual assault will be discussed below during consideration of deprivation of security in Australian prisons.

\section{Deprivation of Autonomy}

The rules in the prison environment are all-encompassing and designed to control every aspect of imprisoned people's behaviour, as shown by the 'total institution' concept. Further, Sykes argues that imprisoned people for the most part are not entitled to know the justification for the rules, which means that they cannot make arguments about the need to change the rules. ${ }^{156}$ Sykes describes the combined effect of this situation as follows:

The frustration of the prisoner's ability to make choices and the frequent refusals to provide an explanation for the regulations and commands descending from the bureaucratic staff involve a profound threat to the prisoner's self-image because they reduce the prisoner to the weak, helpless, dependent status of childhood. ${ }^{157}$

Some Australian examples of the deprivation of autonomy were provided in the preceding section during the discussion of the human rights implications of the 'total institution'. Another example is the use of solitary confinement (which involves deprivation of liberty within the institution). Solitary confinement is common in Australian 'supermax' prisons, as detailed in Chapter 8, but it is also used in mainstream prisons and remand centres. For example, Gucciardo J expressed concern about solitary confinement being imposed on a remandee for 22 or 23 hours per day for a period of 18 months in the Melbourne Remand Centre. ${ }^{158}$ The Victorian Ombudsman has also 'identified a number of cases where prisoners held in solitary confinement for up to 23 hours per day had attempted suicide or self-harm. ${ }^{159}$

155 There is no national data on the breakdown of male and female prison officers, but in Victoria, 30 per cent of prison officers are female: Minister for Corrections (Vic), 'All-Female Prison Squad Completes Tactical Training Minister for Corrections' (Media Release, 9 June 2019).

156 Sykes, above n 106, 73-5.

157 Ibid 75.

158 DPP v Foster \& Ors [2014] VCC 312 [50]-[53].

159 Victorian Ombudsman, above n 23, 40. 


\section{Deprivation of Security}

The probability of being subjected to aggression or violence in prison is much higher than in the general community. ${ }^{160}$ Sykes's observed, following his study, that:

regardless of the patterns of mutual aid and support which may flourish in the inmate population, there are a sufficient number of outlaws within this group of outlaws to deprive the average prisoner of that sense of security that comes from living among men who can reasonably be expected to abide by the rules of society. ${ }^{161}$

Even if a person has not actually been subjected to violence or aggression, the fear of being so invokes a high degree of anxiety, making this one of the most significant pains of imprisonment. Sykes argues that people in prison are in a constant state of anxiety due to both the prospect of being subjected to violence and aggression, and because of their concern about their own ability to cope with such an occurrence. ${ }^{162}$

The focus of Sykes's analysis was violence by imprisoned people against other imprisoned people, which excludes the violence that may be inflicted by staff towards imprisoned people or vice versa. Given that it is quite difficult to access data about violence involving prison staff in Australian prisons, the focus of the following discussion will be on violence by imprisoned people towards other imprisoned people. ${ }^{163}$ This is the most common form of violence in prisons. ${ }^{164}$

160 Sykes, above n 106, 77.

161 Ibid.

162 Ibid 78.

163 For example, in the interviews conducted among NSW and Queensland imprisoned people about their experience of sex and sexual violence in prison, the participants were not asked if they were exposed to such violence by staff. The authors wrote, ' $[\mathrm{m}]$ indful of the need to obtain permission from correctional authorities and cooperation of officers to implement the survey, we did not specifically ask in the interview whether participants had been sexually coerced by, or had consensual contact with, an officer or other member of staff: Ritchers et al, above n 151, 523. Further, the Australian Institute of Health and Welfare data about assault and sexual assault is confined to that perpetrated by other imprisoned people: above n 39, 108-9. The Productivity Commission provides some limited data about the assault of officers by imprisoned people, but not the converse: Steering Committee for the Review of Government Service Provision, above n 22, Table 8A.17. There is brief mention of violence directed at staff in Victorian prisons having 'nearly doubled' in the past five years by the Victorian Ombudsman, above n 23, 37.

164 This analysis also excludes self-harm and suicide as it is concerned with the deprivation of security caused by the threat posed by others. The fact that violence by others is more common is supported by NSW data indicating that 78 per cent of injuries resulting from violence were inflicted by others', with 22 per cent being 'self-inflicted': Tony Butler et al, 'Injury Surveillance in the New South Wales Prison System’ (2004) 15(2) Health Promotion Journal of Australia 151, 152. 
The risk of becoming a victim of violence or aggression is high in Australian prisons. A national picture is gained from Australian Institute of Health and Welfare questionnaires that ask people about their experience of violence upon discharge from prison. These questionnaires have found that 11 per cent of people admit to having been physically assaulted and 2 per cent admit to having been sexually assaulted during their incarceration (8 per cent did not respond to the question about sexual assault). ${ }^{165}$

\section{Types of Physical Violence}

A more nuanced picture is provided by studies in particular jurisdictions and in relation to particular types of violence. Qualitative research about violence in Western Australian prisons reveals that violence by imprisoned people directed at other imprisoned people falls into three main categories: 'payback', 'predatory' and 'impulsive'/'random' violence. ${ }^{166}$

Predatory violence was acknowledged by participants to be the most severe, thus resulting in the most severe forms of injuries, including death in some instances. 'Predatory' violence is usually associated with attempts to recruit those who are seen to be weaker into a group or gang. ${ }^{167}$ It may also be used as a means of accessing goods, such as drugs. This form of violence often encompasses sexual violence. ${ }^{168}$ It has also been termed 'standovers' and its use in Western Australian prisons is corroborated by the Office of the Inspector of Custodial Services. ${ }^{169}$ Standovers have also been detailed by the Victorian Ombudsman, and one specific example provided is the murder of Carl Williams in the Barwon Prison. ${ }^{170}$

'Payback' violence surrounds punishing a person who is viewed as having 'wronged' the perpetrator in some way. An example included in the Western Australian study describes such a situation. If two people were arrested at the same time and one gave the police incriminating information about the other, then the informer would likely be subjected to payback violence once in prison. ${ }^{171}$

165 Australian Institute of Health and Welfare, above n 39, 108-9.

166 Goulding, above n 117, 409.

167 Ibid.

168 Ibid 410.

169 OICS, Vulnerable and Predatory Prisoners in Western Australia: A Review of Policy and Practice (2003).

170 Victorian Ombudsman, above n 23, 36-7. See also Victorian Ombudsman, The Death of Mr Carl Williams at HM Barwon Prison - Investigation into Corrections Victoria (2012).

171 Goulding, above n 117, 409. 
The third category of violence-'impulsive'/'random' violence-may erupt at any time over seemingly trivial matters. It also tends to be the least serious form of violence and may stop as quickly as it started. ${ }^{172}$ As one participant in Goulding's study commented, this type of violence is:

part and parcel of being in prison ... someone looks at the wrong crim in the wrong way and can cop a belting, even if you bump into someone accidentally it can be seen as an insult and end up in a fight ... that sort of violence is usually no big deal, no one usually dies from that. ${ }^{173}$

\section{Sexual Violence}

Research about sexual violence in NSW and Queensland prisons is consistent with the Australian Institute of Health and Welfare data. ${ }^{174}$ However, the NSW and Queensland study provides a more nuanced understanding of the extent of the problem. It shows that for some people this had occurred multiple times - three men said this had happened to them 10-30 times, nine said it had occurred six times, and 15 said it had happened two or three times. ${ }^{175}$ The study also found that 6.9 per cent of respondents had been threatened with sexual assault, and for 18 people this had occurred between 10 and 300 times. ${ }^{176}$

A study in Western Australian prisons found that the rates were higher, with 14 per cent admitting to having been victims of sexual assault and 23.3 per cent saying they had been pressured to 'perform sexual acts' ${ }^{177}$ This study identified the places within the prison where the risk of sexual assault is highest to be within cells (by the person sharing the cell), in shower blocks and in protection units. ${ }^{178}$

172 Ibid 410.

173 Ibid.

174 The study found that 2.6 per cent of people were sexually assaulted during their incarceration: Ritchers et al, above n 151, 521 .

175 Ibid.

176 Ibid.

177 Brian Steels and Dot Goulding, Predator or Prey? An Exploration of the Impact and Incidence of Sexual Assault in West Australian Prisons (2009) 54.

178 Protection units contain a high concentration of people convicted of sex offences because they need protection from those in the mainstream and they may victimise others in the protection unit: ibid $50-1$. 
These statistics are likely to represent the 'tip of the iceberg' for a number of reasons. ${ }^{179}$ Sexual assault in the community at large is widely acknowledged to be under-reported, with an estimated 30 per cent of cases reported to police. ${ }^{180}$ Under-reporting in prison is likely to be exacerbated by certain aspects of the prison population and climate. These include that the majority of imprisoned people disapprove of sex between men and the inmate code of not 'informing' on others. Any breach of this code may cause people to be subject to 'payback' violence, as noted by the Victorian Ombudsman: '[i]n some cases, prisoners have been seriously injured in retaliation for reporting a matter to prison authorities'. ${ }^{181}$ The argument that sexual assault is under-reported is supported by the Western Australian study of sexual assault in prisons, which found that 90 per cent of the 150 participants (who had all been formerly imprisoned) indicated that they thought sexual assault was 'grossly under-reported'. ${ }^{182}$

Another factor, critiqued by Minogue, is the public discourse suggesting that sexual violence in prison is in some sense an inevitability and 'tough luck'. This is demonstrated by jokes about prison rape, such as those relating to dropping soap in a prison shower. ${ }^{183}$ Views about the inevitability of sexual violence have been expressed by authority figures, including a former NSW Corrective Services Minister. ${ }^{184}$ Such discourse is likely to add to the difficulty that victims face in reporting sexual assault to prison authorities.

\section{Overcrowding: Exacerbating the Pains of Imprisonment}

As demonstrated by the statistics provided in this chapter and the continuous growth of the Australian prison population, overcrowding is an increasing problem in Australian prisons. This exacerbates the pains of imprisonment in a number of ways.

179 It is described in these terms by the Western Australian Office of the Inspector of Custodial Services: OICS, Western Australia's Prison Capacity (2016) 16.

180 Australian Institute of Criminology, Guilty Outcomes in Reported Sexual Assault and Related Offence Incidents (Crime Facts Info No 162, 2007).

181 Victorian Ombudsman, above n 23, 35.

182 Steels and Goulding, above n 177, 26.

183 Craig Minogue, 'Why Don't I get the Joke? Prison Rape in the Public Discourse' (2011) 36(2) Alternative Law Journal 116, 116.

184 Ibid. See also Richard Evans, 'Prison Rape: Is it Okay to Make Jokes About Rape in Prison? (2014) Arena 26. 
First, as numbers increase, imprisoned people are more likely to have to share a cell with another person/s (many others in the case of dormitorystyle prison accommodation that is being introduced in some jurisdictions, as discussed in Chapter 8). This further deprives imprisoned people of autonomy and goods and services because they no longer have any space that they have complete control over.

Second, the increase in numbers increases tension in the prison and, consequently, the chances of being subjected to violence and intimidation. This is a phenomenon recently documented by the Victorian Ombudsman in relation to prisons in Victoria, the report highlighting that 'with overcrowding, Victorian prisons are becoming more violent'. ${ }^{185}$ As violence increases, prison management is likely to use 'lock downs' (where all imprisoned people are locked in their cells) more frequently, such that people's deprivation of liberty within the prison is increased. This exposes people to an even greater chance of experiencing violence within cells when they are shared, something found in the Western Australian study of sexual violence to be a particular risk. This was also a concern raised by the Victorian Ombudsman. ${ }^{186}$ The violence may lead to greater use of disciplinary measures, such as solitary confinement, which increases the pain associated with deprivation of liberty, goods and services, and autonomy.

Third, in a situation of overcrowding, such goods and services as there are must be shared by a greater number of people. Accordingly, access to educational and work programs, telephone access to contact people outside the prison, exercise areas and common areas (including showers) are all likely to be rationed as the prison population increases. ${ }^{187}$

Fourth, overcrowding has been found to lead to increased deprivation of liberty within the institution and deprivation of autonomy, with some imprisoned people in Victoria being confined for 24 hours per day. ${ }^{188}$ This is in breach of the requirement in s 47(1)(a) of the Corrections Act 1986 (Vic) that people be allowed out of their cells for at least one hour per day.

185 Victorian Ombudsman, above n 23, 34.

186 Ibid 35-6.

187 Naylor, above n 135, 96.

188 Victorian Ombudsman, above n 23, 40. 
Fifth, the Australian Institute of Health and Welfare has observed that one of the strategies prisons are using to manage overcrowding is frequent transfer of imprisoned people between facilities. They note that this makes 'continuing health care more difficult'. ${ }^{189}$ This is particularly problematic in light of the complex health needs of the prison population outlined in this chapter. It also makes it more difficult for people to maintain regular contact with their family members and friends.

There are very good reasons why overcrowding in Australian prisons must be addressed in order for human rights compliance to be achieved. These are discussed in Chapter 4 (reduce reliance on imprisonment) and Chapter 8 (decent physical conditions). Here it is sufficient to highlight that the consequences of overcrowding contribute to the 'pains of imprisonment' experienced by people in Australian prisons.

\section{Conclusion}

The nature of prisons as a 'total institution' and the pains of imprisonment mean that human rights, such to the right to life, personal security, privacy and humane treatment, are abrogated on a regular basis in Australian prisons (as detailed in later chapters of this book). Further, daily life in prison serves to exacerbate the vulnerability and marginalisation of the population that has been documented in this chapter. This is due to the negative impact of imprisonment on mental health and the pains of imprisonment in general, and particularly the high levels of aggression and violence that imprisoned people experience.

Van Zyl Smit and Snacken have argued that practices built on recognition of the human rights of imprisoned people can reduce the 'pains of imprisonment' and inhibit the 'role stripping' and 'mortification' that occur in prisons as 'total institutions. ${ }^{190}$ Therefore, human rights law offers the potential to improve conditions in Australian prisons for the benefit of people imprisoned in them.

189 Australian Institute of Health and Welfare, above n 39, 7.

190 Van Zyl Smit and Snacken, above n 109, 41. 
This text is taken from Towards Human Rights Compliance in Australian Prisons, by Anita Mackay, published 2020 by ANU Press, The Australian National University, Canberra, Australia.

doi.org/10.22459/THRCAP.2020.01 